\title{
Analysis Using LIDAR and Photointerpretation of Las Murias-Los Tallares (Castrocontrigo, León-Spain): One of the Biggest Roman Gold Mines to Use the "Peines" System
}

\author{
Roberto Matias ${ }^{1} \mathbf{\omega} \cdot$ Bernardo Llamas $^{1}$
}

\begin{abstract}
A comprehensive study of the Las Murias-Los Tallares Roman gold mine (Castrocontrigo. León-Spain) was conducted using Light Detection and Ranging (LIDAR) technology and photointerpretation. The analysis of the mine structure show two main phases of ascending mining works and that the gold recovered by the Romans was at least $510 \mathrm{~kg}$. Although LIDAR lechnology proves to be very valuable and essential to analyzing Roman hydraulic mining structures, there are some aspects that are still hardly decisive given the interpretation difficulties.
\end{abstract}

\section{Introduction}

The Las Murias-Los Tallares Roman gold mine is situated near Castrocontrigo (León-Spain), on the edge of an extensive plain which raises $20-30 \mathrm{~m}$ above the current Eria River (Fig. 1). It is one of the largest Roman mines to have used the "peines" system, expressly used for the hydraulic processing of extensive yel shallow secondary auriferous deposits, which affects a narrow strip $4.6 \mathrm{~km}$ long and $3 \mathrm{~km}^{2}$ of surface area where 60 mine units (peines) have been recorded.

This Roman hydraulic mining system, which can be seen in the aerial images as a series of grooves that converge in a single washing canal, was also used significantly in another two auriferous deposits situated in the province of León. One of them is located several kilometers to the north at Las Moraceras near the town of Priaranza de la Valduema. It measures $5.25 \mathrm{~km}^{2}$ in surface area $(2.8 \times 2 \mathrm{~km})$ and features nearly 40 peines. The other one is located in the town of Las Omañas and measures $5 \mathrm{~km}^{2}$ in surface area $(3.25 \times 1.3 \mathrm{~km})$ with barely 20 peines.

\footnotetext{
Roberto Matias

matiasr roberto@gmail.com

Universidad Polttćcnica de Madrid. ETS. Ingerietos de Minas y
Energia, Rios Rosas 21, Madrid, Spain
}

The Roman mining area of Las Murias-Los Tallares was exposed as a result of a fire that occurred in August 2012, when more than 10,000 ha of valuable pine trees were burnt down. This is why the main mine structures can now be directly analyzed across the surface area.

Adequate field exploration, the reconstruction of the supply hydraulic system, and the use of digital terrain models (DTMs) obtained from Light Detection and Ranging (LIDAR) flights open up a wide range of possibilities when interpreting the various work phases and methods followed at the Las Murias-Los Tallares mine (Fig. 2).

\section{Background}

The Sierra del Teleno is one of the most important reference auriferous mining areas from the Roman Empire and has been studied by several authors (Lewis and Jones 1970; Bird 1972; Domergue 1973; Sáenz and Vélez 1974; Pérez Garcia 1977; Domergue and Hérail 1978; Sánchez-Palencia 1980; Perea and Sánchez-Palencia 1995; Matias 2006; Dieulafait el al. 2008; Matias and González-Nistal 2014; Justel Cadierno et al. 2014; Femández-Lozano et al. 2014; Femández-Lozano and Gutiérrez-Alonso 2016; Matias and Llamas 2017).

The first modern approach to an analysis of the ensemble of Roman mines in the Eria River basin was by the engineers Sáenz and Vélez (1974, pp. 97-109), who evaluated the total 


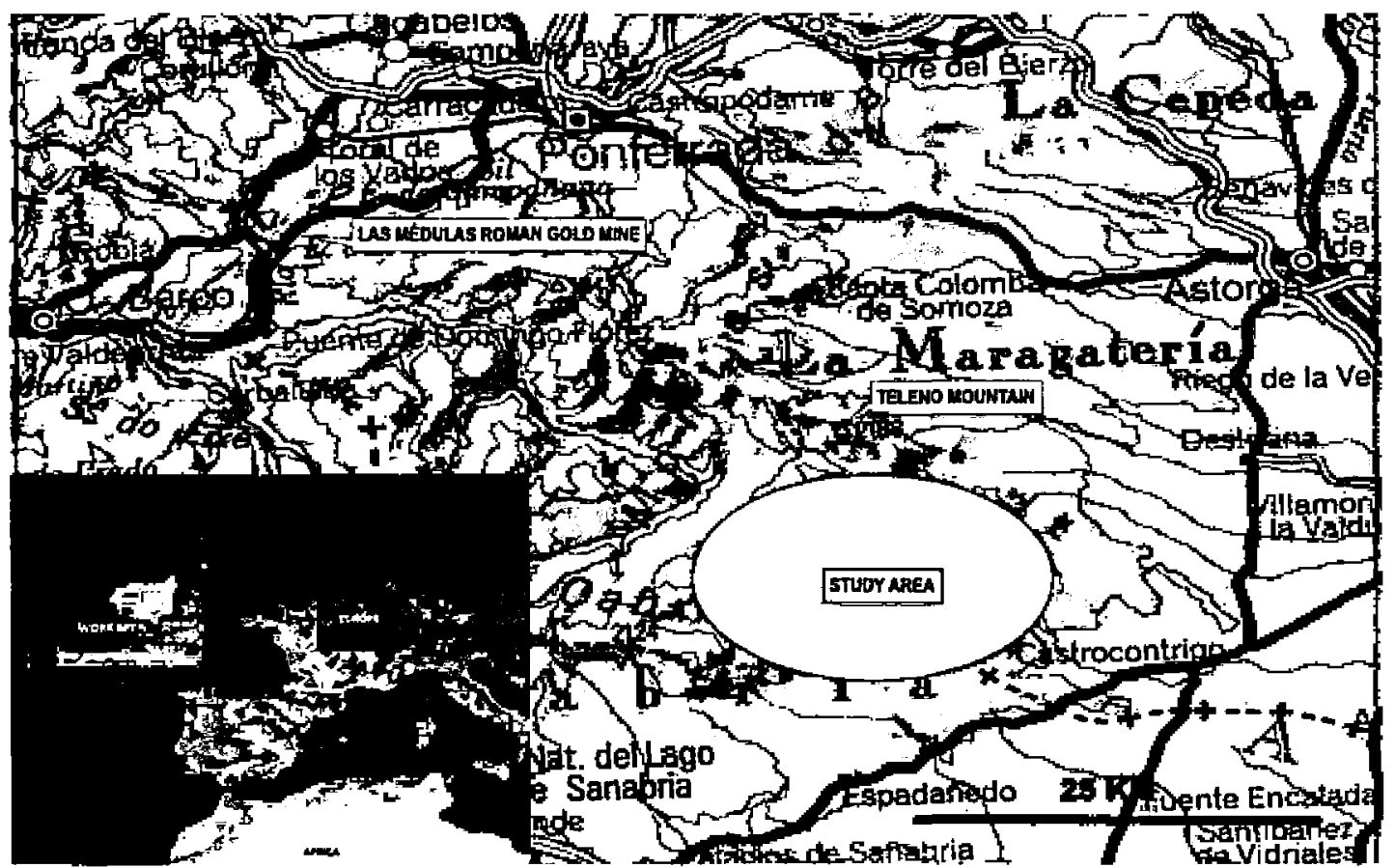

Fig. 1 Location of the study aren (image: LANDSAT, map: IGN 1:200,000)

mined volume of the Roman works in $20 \mathrm{Mm}^{3}\left(10 \mathrm{Mm}^{3}\right.$ in a single mine: Las Murias-Los Tallares).

Contemporary of Sáenz y Vélez, the mine research work was done by geologist Luis Carlos Pérez for the company Rio Tinto Patiño, S.A., in order to evaluate the possibility of reopening the secondary gold ore deposits in this area (Pérez Garcia 1977, pp. 186-254). Pérez evaluated the materials mined at Las Murias-Los Tallares in $8 \mathrm{Mm}^{3}$. His main contributions to the knowledge of this area have been the following:

- To establish a system of alluvial fans from the denudation of the Sierra del Teleno mountains as the main source of the secondary ore deposits.

- The geological exploration of the inner structures of the Miocene alluviums and quatemary terraces.

- To determine the gold content of the alluvial materials and their mining potential.

At the start of the 1980s, archeologist Javier SánchezPalencia outlined up to 26 Roman mine work areas in alluvial lands on the banks of the Eria River, questioning the validity of some of those suggested by Sáenz and Vẻlez (SánchezPalencia 1990).

The first detailed map of the hydraulic system of the Roman mines at Teleno situated above an elevation of 1400 (Matias 200\$) was published barely 10 years ago which would be complemented shortly thereafter with new data on the mine structures and a proposal regarding the evolution of the development of the mines (Matias 2006). The existence of a new and extensive primary gold ore deposit was recently defined on the southern slope of the Sierra del Teleno mountains, well known by the Romans (Matias and GonzalezNistal 2014), which offered a new outlook on the source of the gold in the secondary ore deposits in the area.

\section{Material and Methods}

The operational method for analyzing the Roman mine struc* tures is mainly based on exhaustive exploration of the ground for an initial reconstnuction of the mine morphology, supported at all times by existing maps and the possibilities offered by aerial photographs (orthoimages) both for the precise location of important elements as well as to obtain an adequate view of the ensemble. Added to all of this is the use of LIDAR data to obtain a local and detailed DTM to highlight, differentiate, and analyze the evidence of anthropic activity on the ground. This all-new technique opens up an important range of possibilities as it enables very reliable observation of the ground below the vegetation layer.

As concems, the particular use of LIDAR technology in Roman gold mining, specific and multi-disciplinary work has already been done (Fonte et al. $20 \mathrm{~J} 4$ ) very briefly outlining the advantages and limitations with everything in the end passing through exhaustive field exploration with adequate criteria and parameters due to the difficulties of interpretation as a result of the deterioration of the evidence and the overtapping 
Fig. 2 Onthoimages (PNOA 2006-0.5 $\mathrm{m}$ and PNOA 2014-

$0.25 \mathrm{~m})$ of the Roman mine before the forest fire of 2012 (a) and after (b). DTM. LIDAR slsowing the roman mining structures (c)

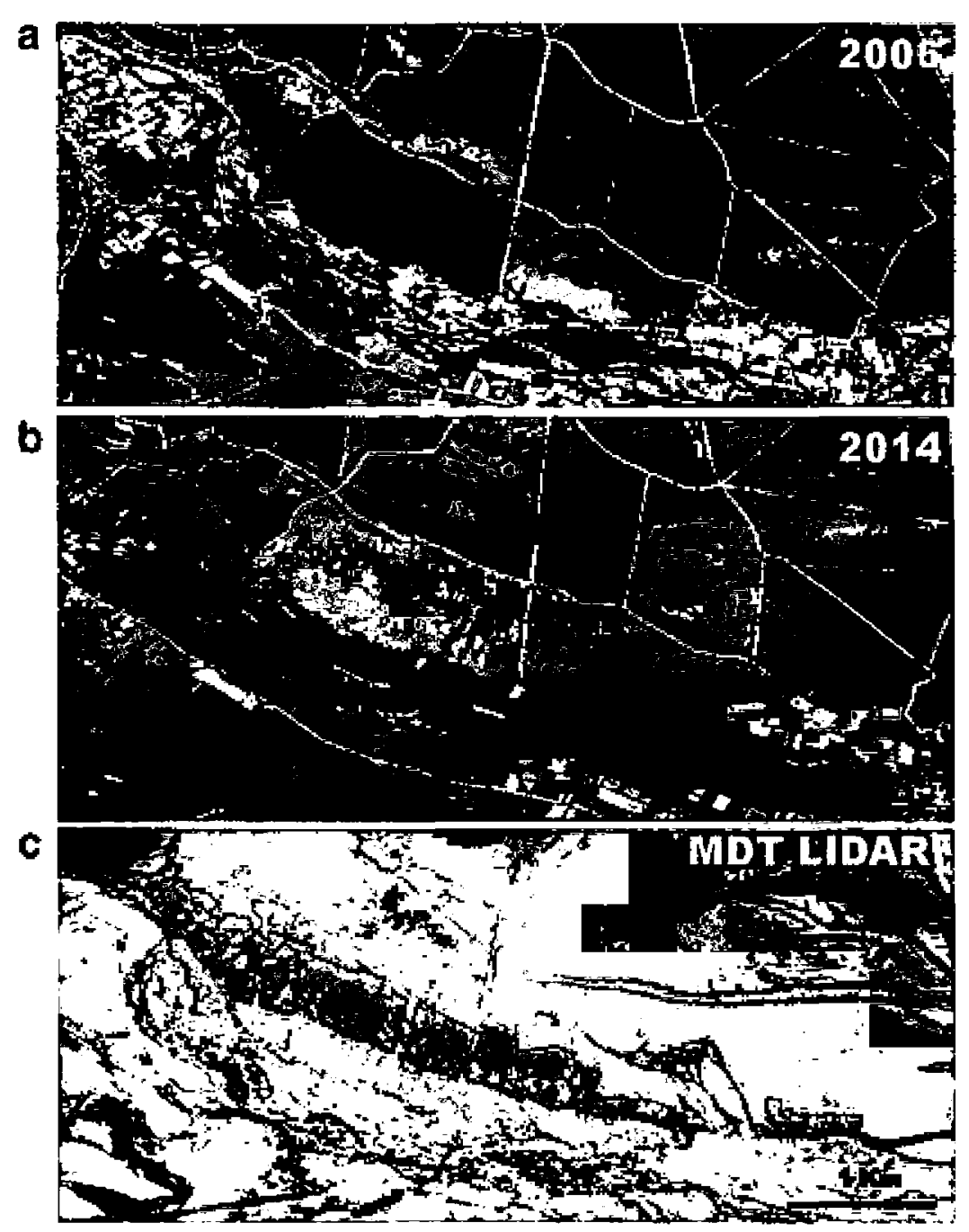

of structures over the nearly 2000 years of anthropic use of the land.

The source of all of the images and the digital maps (historical aerial photographs, orthophotographs, LIDAR, etc.) is the IGN (Spanish National Geography Institute), promoter of the project PNOA (National Plan of Aerial Ontophotography) as well as the Institute for Agricultural Technology of Castilla y León (ITACyL), which are freely disseminated for noncommercial use. They were processed and the DTM was generated based on LIDAR files using the commercial programs Arcgis 10.3 and Global Mapper 16.0, respectively.

The metadata (ISO 19115:2003) of the LIDAR 2010 flight used are the following:

Nominal density, $0.5 \mathrm{p} / \mathrm{m}^{2}$

Nominal distance, $1.4 \mathrm{~m}$

Altimetric precision points, RMSEz $\leq 0.20 \mathrm{~m}$

Altimetric precision DTM, RMSEz $\leq 0.5 \mathrm{~m}$

Grid, $5 \times 5 \mathrm{~m}$
Multiple returns, 4

Classification, automatic

Geodesic reference system, ETRS89

\section{Analysis of the Las Murias-Los Tallares Roman Gold Mine}

The detailed study of the different aspects (geology, hydraulic system, mining areas, tailings, and work methods) comprising this great mine will make it possible to better understand the approaches used by Roman engineers to make use of the auriferous alluviums and their evolution, both in space and over time.

In general, this Roman mine is known for the great longitudinal extension $(4.6 \mathrm{~km}$ ) with barely $400 \mathrm{~m}$ of maximum width. The mining works is located between elevations of 985 and $920 \mathrm{~m}$ and was done on the edge of a fluvial terrace. The 
tailings from the washing process were accumulated by hydraulic drag at the exit of the mines on the current Eria River floodplain.

\section{Geology}

The area studied is located on the eastem edge of the Sierra del Teleno Mountains, a well-known mountain chain characterized by the abundance and types of auriferous one deposits and Roman mines. The highest altitude is reached by the Teleno Peak at $2188 \mathrm{~m}_{\mathrm{m}}$, the maximum elevation of a range which extends uninterruptedly in a N 120 E direction for more than $60 \mathrm{~km}$. The primary geological materials comprising the Sierra del Teleno are Paleozoic sandstone, slate and quartzite (IGME, 1981), the ages of which are between the Cambrian ( 570 million years) and Silurian ( 400 million years) periods.

The great geological structures reflect a dominant NW-SE direction corresponding to Hercynian folding. The Ordovician quartzite stands out due to its influence on the relief of the current landscape. The differential erosion of this quartzite has given rise to steep headlands.

The ensemble was elevated during the Alpine orogeny (45-15 Ma) with a succession of several geology phases of intense meteorization. The tropical climate conditions of this area during the Miocene (37-15 Ma) led to major accumulations of alluvial deposits of a characteristic red color. There are great discordant beds of Miocene materials (clay and round pebbles) from the current Eria River banks to an elevation of 1200 (in the towns of Pozos and Corporales) which were later eroded with the remains filling the foot of the forest in gentle layers. The most modem materials (Quatemary) are comprised of fluvial terraces as a result of the remobilization of the prior levels (Fig. 3).

\section{Mettalogeny}

The mettalogenetic profile of the primary gold mineralization distributed within the Sierra del Teleno and surrounding areas comespond to stratoid and hydrothermal quartz and sulfide (arsenopyrite), characterized as epigenetic and discordant, relating to polyphase tectonic structures embedded in detritical rocks in greenschist facies (Tomos 1992; Tomos and Ribera 1993). These authors observed a spatial disconnection with the shear zones yet related, however, to extensional structures associated with fold lines. The recent study of various primary gold ore deposits in the Teleno region have made it possible to definitively consolidated this mettalogenetic model (Gómez Femández et al. 2005, 2010, 2012).

The specific type of this gold mineralization, which is structurally connected to rocks of low metamorphism with barely or no direct relationship to magmatic sources, fits within what was recently defined as orogenic gold (Ridley 2013 ).
The elevation and later degradation of the Sierra del Teleno by atmospheric agents generated major accumulations of alluvial deposits in the Neogene (Miocene) of a characteristic red color where there are particles of gold (nuggets) mechanically carried from their places of origin following a system of altuvial fans towards the east. The remobilization of these materials gave rise to the formation of a system of thin fluvial terraces (T-1, T-2, T-3, and T-4) with higher gold content than that of the original Neogene materials due to natural reconcentration (Pérez García 1977; Hérail 1984).

The Romans mined all the thickness of the T-2 terrace until the Miocene period, between 5 and $8 \mathrm{~m}$, at Las Murias-Los Tallares (Fig. 4a), which exceptionally reached $15-20 \mathrm{~m}$ only on the NW end where a drag cut was created near the Paleozoic subsirate.

The multinational mining company Rio Tinto Patiño, S.A., conducted a preliminary washing pan sampling of terrace $\mathrm{T}-2$ with $13185-\mathrm{kg}$ samples, one of which reached a grade of $204.6 \mathrm{mg} / \mathrm{m}^{3}$. The primary sampling was conducted through 11 shafts using a $3.5 \mathrm{t}$ clamshell bucket with a diameter of $1.40 \mathrm{~m}$ hanging by a cable from a crane. It reached $40 \mathrm{~m}$ deep (Fig. 4b). The shafts were created following the $\mathrm{N}$ edge of the Roman mine after their work areas (Pérez Garcia 1977, pp. 186-254).

The size of the gold particles from terrace $T-2$ is submillimetric. Only as an exception are some of them $3.5 \mathrm{~mm}$ long. They exclusively pertain to the terrace $\mathrm{T}-2$ area where nonlaminar particles (grains and distorted shapes) have also been found which clearly indicate possible Paleozoic origin (Fig. 5).

Grain size analyses revealed the existence of a significant portion of fine gold $(<0.08 \mathrm{~mm}$ ), practically impossible to recover in an economic manner. The percentage of this fine gold out of the total grade is around $20 \%$, and even $50 \%$ in some cases. Thus, the following results were found at terrace $\mathrm{T}-2$ considering only the recoverable gold:

- Volume of alluviums researched, $16 \mathrm{Mm}^{3}$

- Mean Au grade, $58 \mathrm{mg} / \mathrm{m}^{3}$ (maximum value, $81.5 \mathrm{mg} \mathrm{Aw}$ $\left.\mathrm{m}^{3}\right)$

- Total Au, $0.928 \mathrm{t}$

\section{Hydraulic System}

The Las Murias-Los Tallares supply (Matias and Llamas $201 \%$ ) was comprised of two main canals (CEr-01 and CEr02), which got water from the Eria river and a third supporting one (CEr-03), situated quite well above the maximum mine elevation which was sourced by the Formosina brook near the town of Morla (Fig. 5). To a greater or lesser extent, all of these canals could have been involved later in the exploitation 


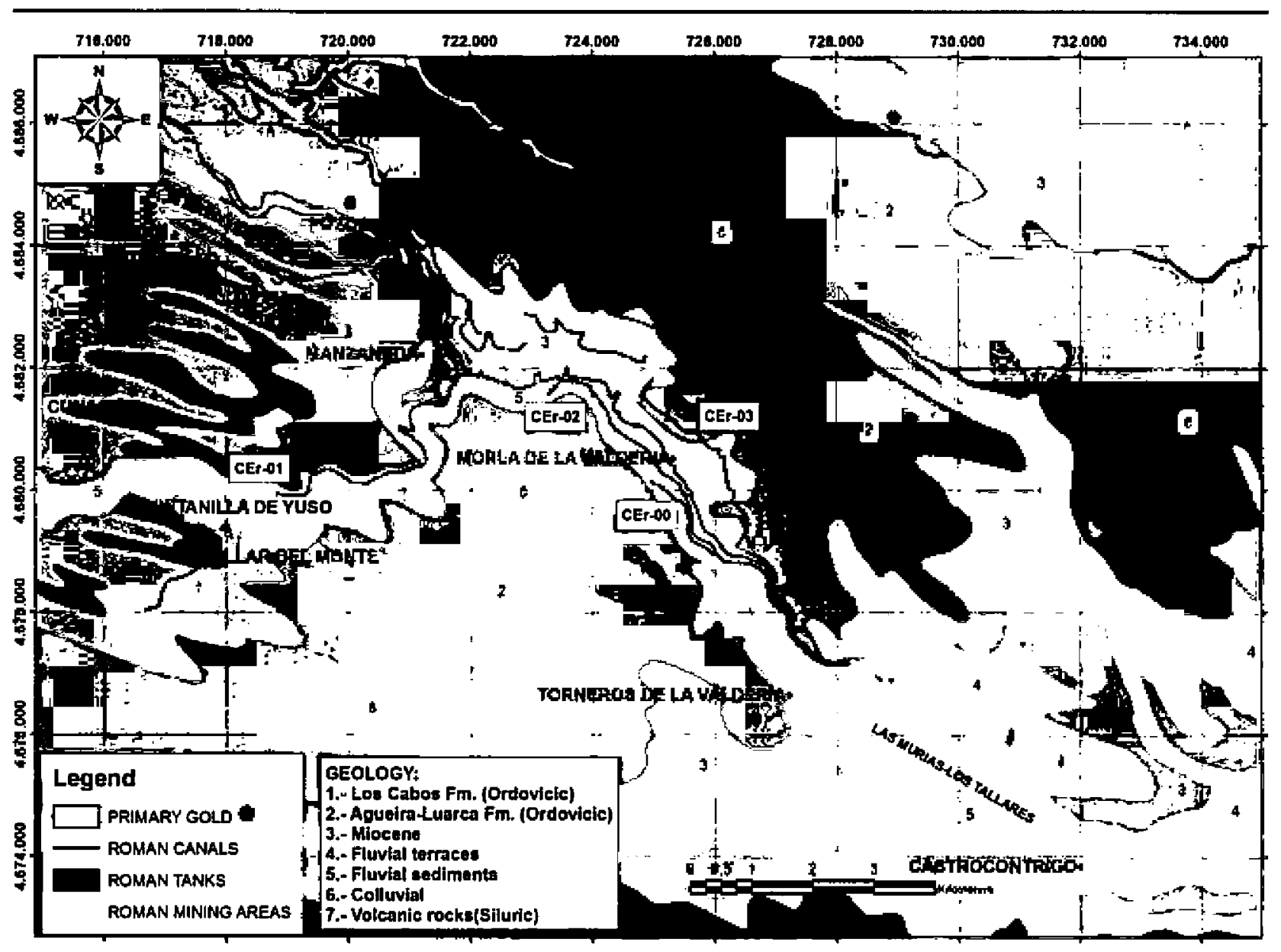

Fig. 3 Geologic map of study area (source: authors, adapted from SIEMCALSA)

of the other auriferous ore deposits situaled upstream, especially canal CEr-02, due to the longer route (Table 1).

The maximum supply elevation for the Las Murias-Los Tallares Roman mine is $985 \mathrm{~m}$, meaning both canals could have been operative from the very beginning which would have allowed simultaneous use of the entire hydraulic system during the initial mining work phase, sourcing both the $\mathrm{E}$ as well as the $\mathrm{W}$ ends of the mine without producing any type of interference between the various gullies, the pace of which would have been marked by the availability of water and tabor. Nonetheless, and with some exceptions, a clear progression towards the $W$ of the mine work sites can be observed in the mine canal intersections. Canal $\mathrm{CEr}-0 \mathrm{l}$ was no longer available for the final phase of the work.

The supply capacity (Table 2 ) of these canals for annual continuous service for the entire supply system under ideal conditions was $20.2 \mathrm{Mm}^{3}\left(55,296 \mathrm{~m}^{3}\right.$ per day).

\section{Mining Tanks and Canals}

Up to six regulation-distribution tanks have been located (Table $\exists$ and Fig. 6). Two of them are still in an acceptable state (DEr-01 and DEr-03). They are systematically found near the mine faces (Figs, 7 and 80 ).

There are a number of mine canals between tanks DEr-03, DEr-04 and the adjacent tanks responsible for taking the water to the faces with several derivations between them and the mine work sites, reflecting a maze that is complex and difficult to explain as there are also modern roads overlapping the old watercourses. In the case of the area around deposit DEr-03. one can see how some of these derivations were lind out at different times with a predominant, deeper one towards the east. In summary, it could be said that it is an apparently labyrinth-like structure which proves different periods of work in the western third of the mine, supplying different sectors.

After the westem third of the mine, the water was taken through a single canal situated near the edge of the mine work sites and then would derive as necessary to supply the various faces (Fig. 9b).

\section{Peines System as a Roman Mining Exploitation}

Jones and Bird (1972, p. 61-62, sectors I and II) classify the method followed at Moraceras as the result of "giant plowing" 
Fig. 4 a Schematic section showing geology and Roman mining works (from Pérez Garcia 1977). b Inside a Río Tinto Patiño prospecting shaf $(1.4 \mathrm{~m}$ b)

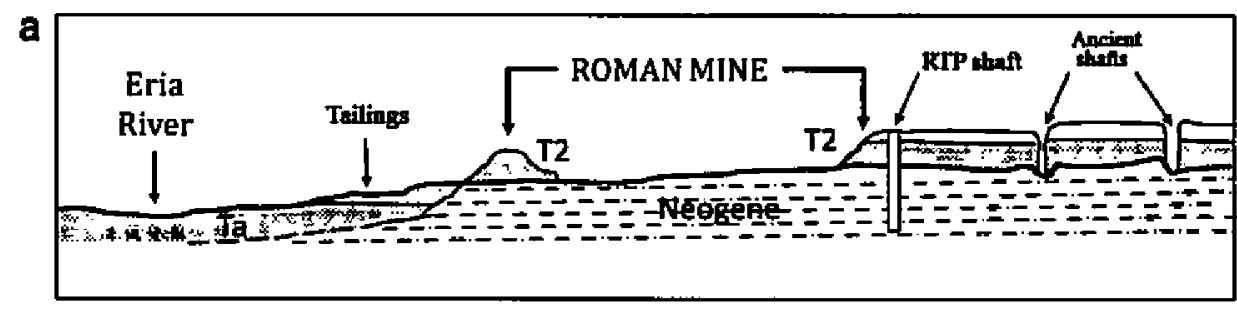

b

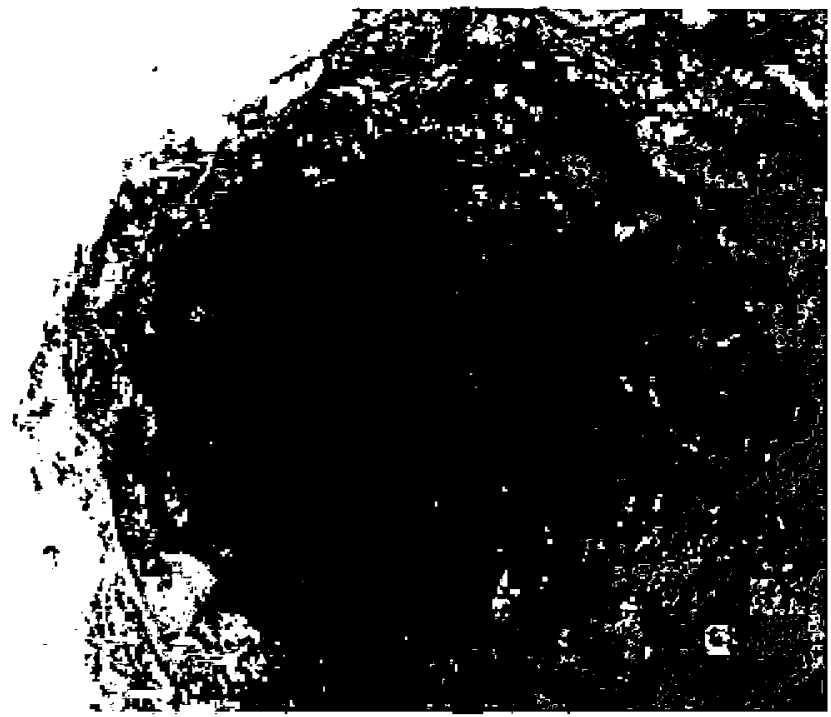

making reference to the use of the technique known as ground situicing. They also suggest that water was also used to first remove the tailings cover (hushing).

Domergue analyzed this specific type of Roman hydraulic mining in-depth for the first time ever, making reference to the three main Roman mine sites of this kind located in the province of León, although he mainly focused on those found at
Las Moraceras (Priaranza de La Valduema) and Las Omañas (Domergue 1973; Domergue et al. 1988). He used the tenm "chantier-peigne" to establish similarities between this method and ground sluicing, used in the nineteenth century Califomia gold mines, yet clarified different aspects. He also defined a means of operation for each mine work unit largely consisting of the manual layout of rectilinear and parallel
Fig. 5 Submillimeter gold nuggets of the terrace T-2. Nole the low degrec of rolling

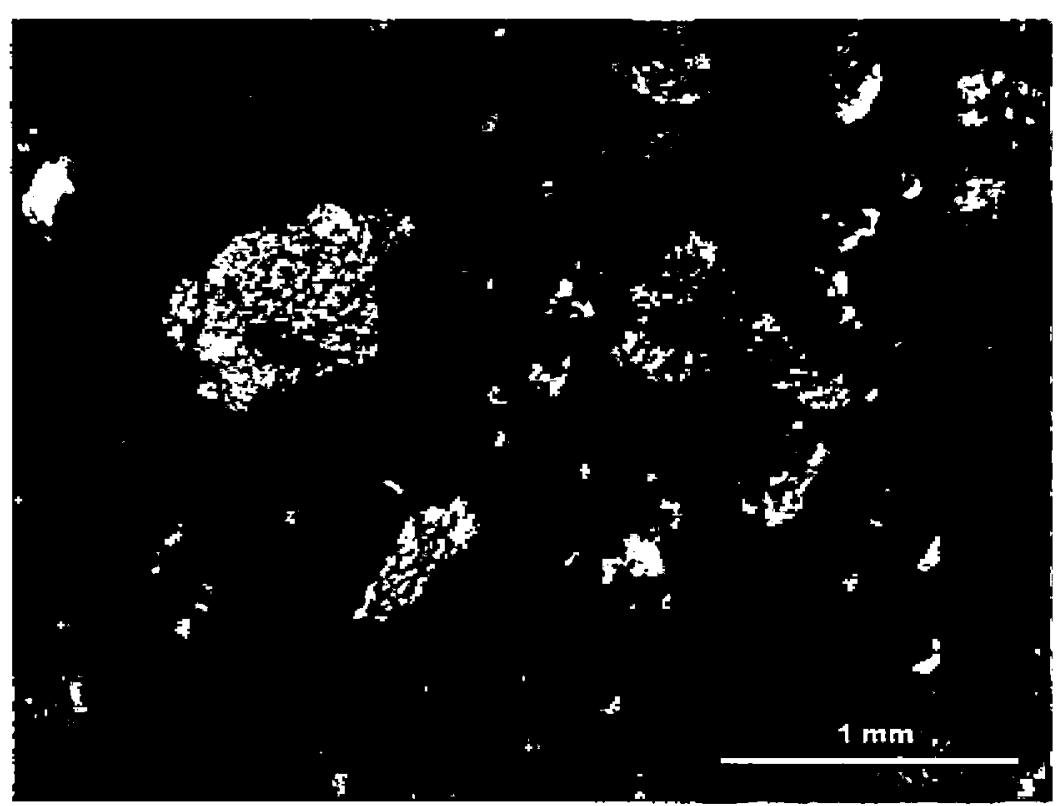


Table 1 Supply canals. Las Murias-Los Tallares: Roman gold mine

\begin{tabular}{lllll}
\hline Canal & $\begin{array}{l}\text { Lenglh } \\
\text { (km) }\end{array}$ & $\begin{array}{l}\text { Elcration } \\
\text { intake }\end{array}$ & $\begin{array}{l}\text { Supply } \\
\text { slevation }\end{array}$ & $\begin{array}{l}\text { Approx. average } \\
\text { slope }\end{array}$ \\
\hline CEr-01 & 7.75 & 1000 & 985 & $02 \%$ \\
CEr-02 & 169 & 1046 & 993 & $0.3 \%$ \\
CEr-03 & $1.3+3.3$ & 1078 & 1014 &. \\
\hline
\end{tabular}

These elevations wete obtained from the existing maps (IGN) without any topographic measurements

trenches separated $15 \mathrm{~m}$ from each other where water was released to deepen the trenches $1-2 \mathrm{~m}$ and drag the auriferous sediments towards the washing canals which were located outside the drag areas. Each mine unit features a single evacuation canal where all the parallel grooves lead. This process would have to be supported by plenty of labor to facilitate the sediment dragging as well as separate the largest pebbles. With a width of $3.5 \mathrm{~m}$, the washing canals (sluices) would be defined by pebble walls on each side with the back covered in these materials as well. The deepening work to reach the bedrock would be done in successive 1-2 $\mathrm{m}$ cycles all along the length of the grooves or in different sectors until the end of the mine was reached (Domergue and Hérail 1978, pp. 263268; Domergue 1990, pp. 465-466).

Sảenz and Vélez (1974, pp. 105 y 109) define the look of the Las Murias-Los Tallares Roman mine as a "plowed field," calling the different mine units "mine shovels" (due to their similarity to this tool), using the term "valley mining" for this type of work without going into any details concerning the specific means of operation of this mine yet another section of their publication (Sáenz and Vélez 1974, pp. 56-60) defines the work method in a general manner. Their description also supports the combined use of water and labor to open and deepen the grooves with the simultaneous participation of 2000-3000 operators and the possibility of working at different heights over the same point in different phases clearing the land in several layers.

Sánchez-Palencia define this system as "plowed grooves" (Sánchez-Palencia 1977, pp. 66-7I) and indicate a work procedure similar to the one described by Domergue with excavation of the main trench first where the water was released. thereby rejecting the suggestion by Sáenz and Vèlez of work being done at the same point at different heights in several phases. In their study on Roman auriferous mining in the Eria basin, no additional details in particular are added except that the mining was done in an ascendant manner (SánchezPalencia 1980, p.225).

\section{Extraction Procedures}

There are 60 mine units at the Las Murias-Los Tallares Roman mine with each one defined by groups of a specific number of trench canals (usually 6-8) which converge in a common evacuation corridor (Fig. 9a, b). This arrangement indicates that each group of canals was worked at a certain time either simultaneously, alternatively, or a combination of the two until the basement or bedrock was reached, determined in this case by the Miocene (Pèrez Garcia 1977, pp. 186-87, Fig. 36). The habitual width of the grooves is $13 \mathrm{~m}$, with some values that may reach $16 \mathrm{~m}$ or even be as low as $8 \mathrm{~m}$, such as in the areas of the most shallow sediments (Vallico la Escoba).

Pursuant to Domergue and other authors, the design of the Roman mine work areas as far as the planning and continuous supply of water largely correspond to the technique known in modern times as ground sluicing, which was widely practiced throughout the world during the mid-nineteenth century Gold Rush, the precursor of today's hydraulic mining, which already used pressurized water. hydraulicing (Phillips 1867, p. 149; Waldeyer I873, p. 390). As concerns this technique, some authors indicate the presence of tanks at the head of the mines as evidence of the booming technique deriving from ground sluicing, which consisted of releasing large quantities of water from these tanks in an isolated manner (Longridge [9]0, p. 196).

Putting the observations made by other authors and specifically referring to the Las Murias-Los Tallares Roman mine, the following main characteristics can be readily seen:

- The existence of at least two different and overlapping work phases (Fig. 9a)

- The systematic presence of residual rock on the edge of Ierrace T-2 where the evacuation canals were opened.

- Significant accumulation of thick tailings at the exists of the evacuation canals, with the complete absence of any clay elements and their heterometric nature standing out (Figs. 10 a, b).
Table 2 Supply capacily $\left(\mathrm{m}^{5}\right)$. Las Murias-Los Tallares Remas gotd mine

\begin{tabular}{lllllllll}
\hline & Length & Slopt & Width & Depth & Flow & 1 day $\left(\mathrm{m}^{3}\right)$ & 1 month $\left(\mathrm{m}^{3}\right)$ & 1 year $\left(\mathrm{m}^{3}\right)$ \\
\hline CEr-01 & $7.75 \mathrm{~km}$ & 0.2 & 0.90 & 0.45 & 0.22 & 19,008 & 570,240 & $6,937,920$ \\
CEr-02 & $16.9 \mathrm{~km}$ & 0.3 & 0.90 & 0.45 & 0.27 & 23,328 & 699,840 & $8,514,720$ \\
CEr-03 & $1.3 \mathrm{~km}$ & 0.2 & - & - & 0.15 & 12,960 & 388,800 & $4,730,400$ \\
Available flow rales & & & Total & 55,296 & $1,658,880$ & $20,183,040$ \\
& & & & CEr.02 and 03 & 36,288 & $1,088,640$ & $13,245,120$ \\
\hline
\end{tabular}


Table 3 Roman gold mine tanks. Rcgulation tunks Las Murias-Los Tallares Roman gold mine

\begin{tabular}{lllll}
\hline Tank & Location & Dimensions & Capacity $\left(\mathrm{m}^{5}\right)$ & Durect supply \\
\hline DEr-01 & La Pradera & $210 \times 15$ & 4725 & CEr-02 \\
DEr-02 & La Pradera & $130 \times--$ & - & CEr-01 \\
DEr-03 & La Pradera & $\left(3200 \mathrm{~m}^{2}\right)$ & 4000 & - \\
DEr-04 & La Pradera & & & - \\
$(\mathrm{DEr}-05)$ & Vallico la Escoba & $\left(18,000 \mathrm{~m}^{2}\right)$ & 8000 & - \\
$(\mathrm{DEr}-06)$ & Cuesta del Pinar & $\left(20,000 \mathrm{~m}^{2}\right)$ & 10,000 & - \\
\hline
\end{tabular}

- Very little slope at the bottom of the mine $(=1.5 \%)$, which is practically even in all sectors (Fig. II, Table 4).

In order to understand the specific supply process for this auriferous deposit, once must keep in mind that the lower level of the main mine is some $8-10 \mathrm{~m}$ deep with respect to the original ground of terrace T-2. However, the intermediate divisions between each groove where large pebbles sometimes accumulate barely rise $2-3 \mathrm{~m}$ above the bottom of the grooves. With an average separation of $13 \mathrm{~m}$ between the grooves, it is not possible to maintain the stability of the ground for heights of 8-10 m. Under these conditions, it would not be very suitable to apply the concept generally accepted up to now of separating the large pebbles contained in the in situ alluvium but rather keep them there throughout the washing process. On the other hand and although there are many piles of pebbles inside the mine areas, obviously as a result of the final phase of the work, most of the tailings, which are already free of the clay fraction, are deposited at the exit of the various peines on the edge of the terrace. They all take on a characteristic and individual dejection cone shape, clearly topped off by an evacuation canal responsible for taking these materials further and further away. A number

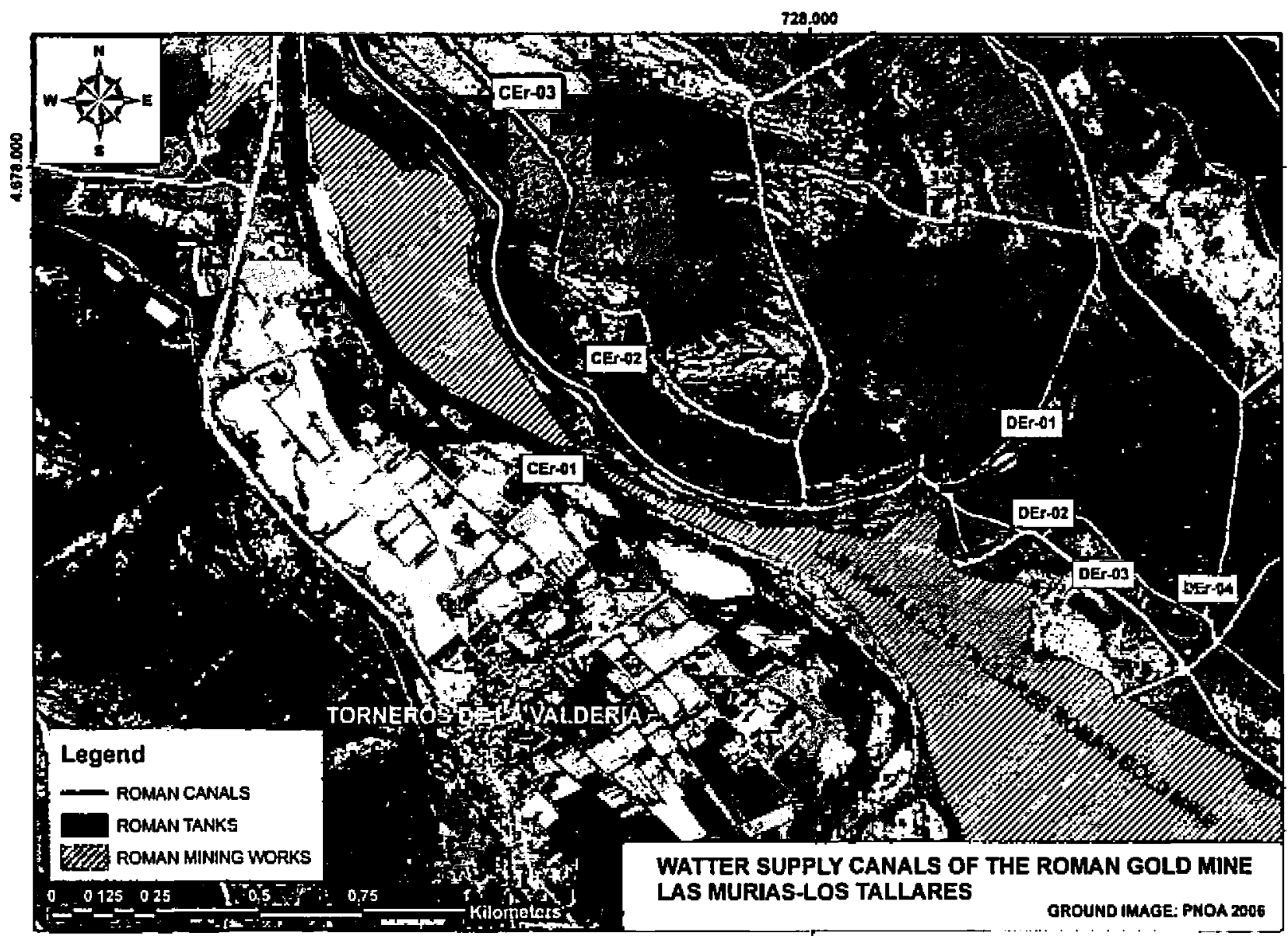

Fig. 6 Artival of canals to the exploitation of Las Muras-Los Tallares 


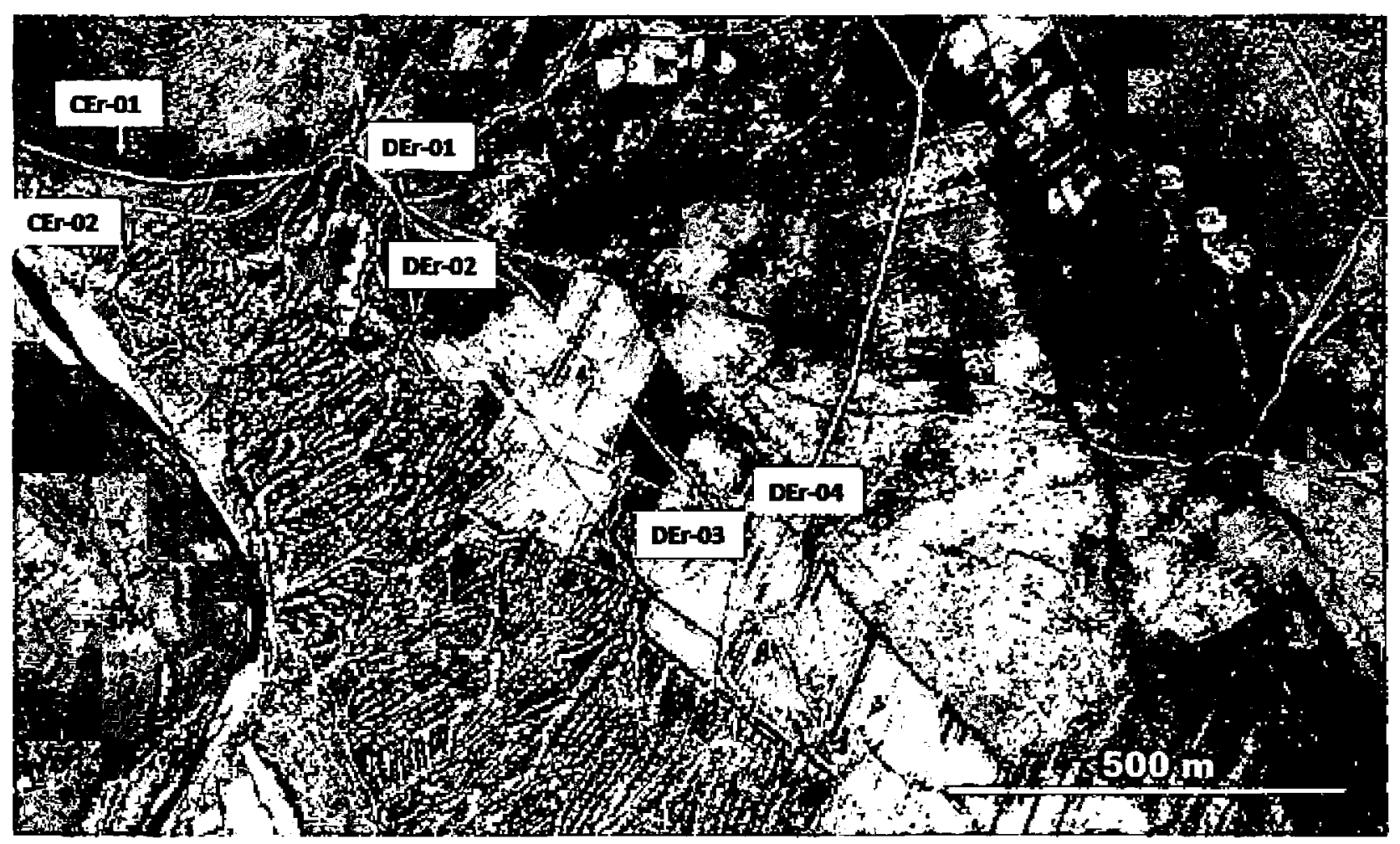

Fig. 7 Location of the main regulation-distribution tanks in the frame of the LSAF Flight 195657

of large pebbles can be observed among the tailings which were not manually deposited.

Since the mine gets deeper and it is necessary to maintain the hydraulic slope for the alluvium to burst and the tailings to leave, the evacuation cantal gets progressively longer over the debris. The big difference in height between terrace $\mathrm{T}-2$ and the Eria River floodplain (20-30 m) allowed for a large accumulation of tailings in the initial stages over which the evacuation canals now observed on the ground would gradually extend. This fact can still be documented by the existence of some surface peines situated on the edge of the terrace and later abandoned as the adjacent work progressed, the tailings from which would directly accumulate on the edge of terrace $\mathrm{T}-2$ without having developed the characteristic evacuation canal.

Thus, the mining system proposed by other authors must be reapproached and updated without invalidating some of their arguments yet adapting them to the reality of the ground which can now be better analyzed with the new technologies. Given the immense accumulation of heterometric tailings deposited in the Eria River floodplain, the piles of pebbles ("murias") observed in mining areas pertaining to the final phase of the mining work are not at all representative of all of the tailings contained from the processed materials. These pebbles were manually separated for practical reasons during one of the many mining work cycles (the final one, in this case) given that the evacuation of the debris had to be combined with the gold recovery in the washing canals.

Although it has been traditionally considered that the piles of pebbles are generally situated near the washing areas, Pérez Garcia (1977), p. 187) also observed the circumstance on the ground that "the crests between the canals of one peine are already reduced in many places to the minimum expression and are even completely artificial with just piles of large blocks remaining, nothing more, indicating the methodic cleaning done on the neogenic bedrock." We can currently corroborate this fact in the section produced by illegal excavation at the base of a group of peines to extract materials used to repair roads following the 2012 fite (Fig. 12).

In view of the above, two facts must be taken into consideration which are habitual in ground sluicing:

- The entire auriferous level has been cleaned, even slightly deepening the bedrock (Miocene).

- The piles of thick pebbles would have been eliminated by means of a current of water if deepening had continued.

One must always remember that this hydraulic mining system was designed to handle large bodies of materials, meaning the objective is to place a significant quantity of alluvium into movement as a "sludge current" (debris flow) to get it through the washing canals. 
Fig. 8 a Detail of the current state of the roman mine tank DEr-03 with its channel of cvacuation to the bottom. B DTM-LIDAR from the eastern end of the Las MuriasLos Tallares mine, where the anthropic structures identified as potential tanks (DEF-0S and DEr06) a
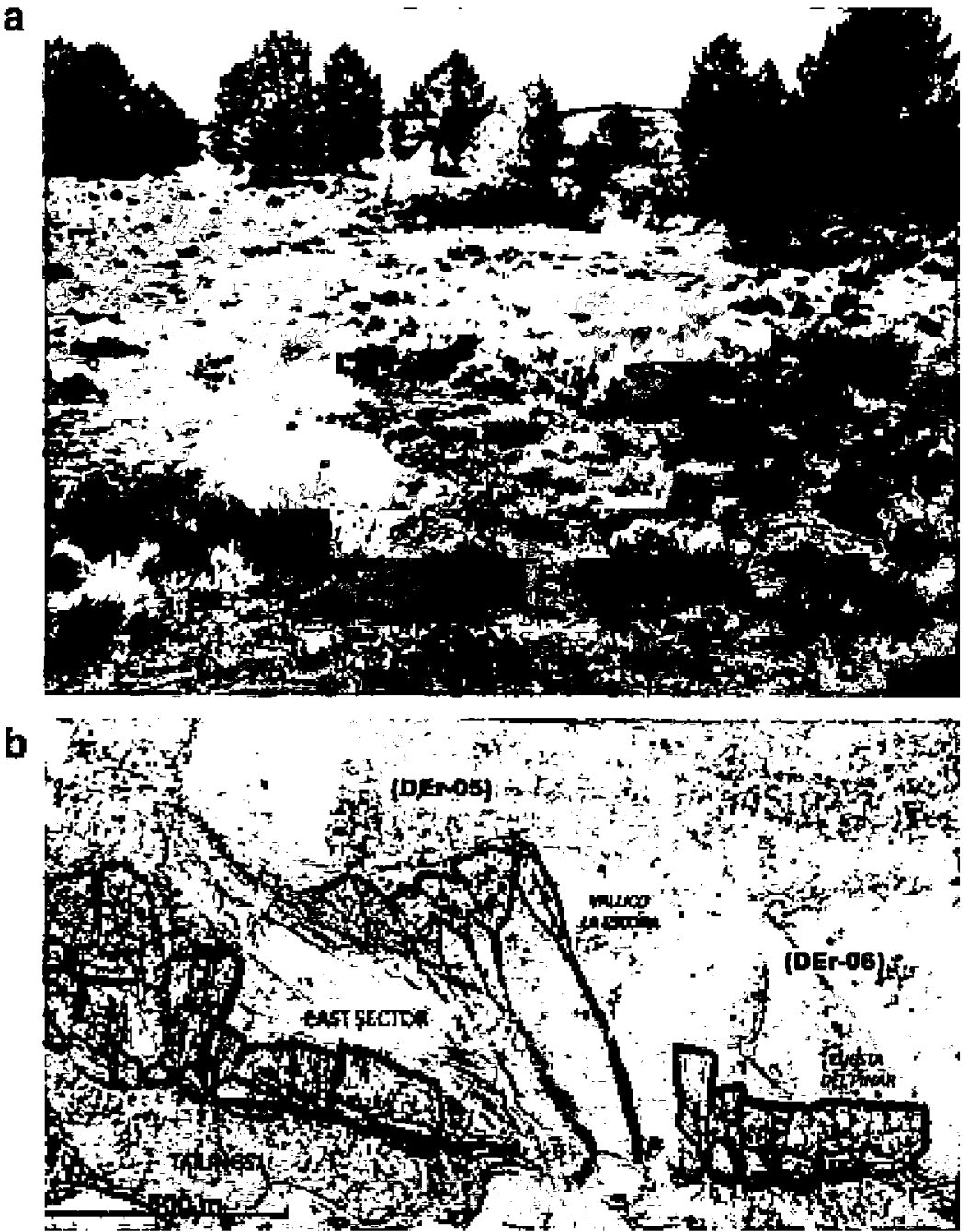

The gold extraction and recovery process can be considened to have consisled of the following steps:

- The construction of a hydraulic supply system and regulation-distribution tanks.

- The layout of the mining canals to take the water to the various mine work sites.

- The initial layout of the grooves and evacuation canal with the use of water and labor, all while eliminating the thin tailing cover.

- The construction of washing canals (see section Hydraulic System).

- The start of the extraction work in one or more grooves at the same time, slightly deepening the canal all along the length and by sectors using a combination of water and tabor. The largest pebbles were separated on the intermediate berms to more easily retain the gold in the wasting canals and evacuate the large tailings. An even slope must be maintained in this phase to prevent obstructions.
- Once the desired depth is reached, the flow of water is internupted to allow for the manual removal of the auriferous concentrate which is later washed out either in situ or elsewhere.

- All of the thick debris previously removed is evacuated, and the flow of water is reestablished to drag them to the grooves. This frees up the berms to lower them and continue digging deeper, separating the large pebbles.

- The washing canals are rebuilt.

- The extraction process begins again. The cycle is repeated until the sterile substrate is reached.

On the other hand, there are also some peines which have not been depleted to the end of the supply canals (Figs. 13 and 14), which means the extraction could have been done up to the bedrock and maintaining the total height of the exploitable auriferous bank. This work process has the following advantages: 
Fig. 9 a Structure of the Roman gold exploitation Las Muriss-Los Tallares. b Detail of the Roman exploitation: exploitation canals (green lines), work phases (blue and red lenes), and accumulations of sterils (brown)
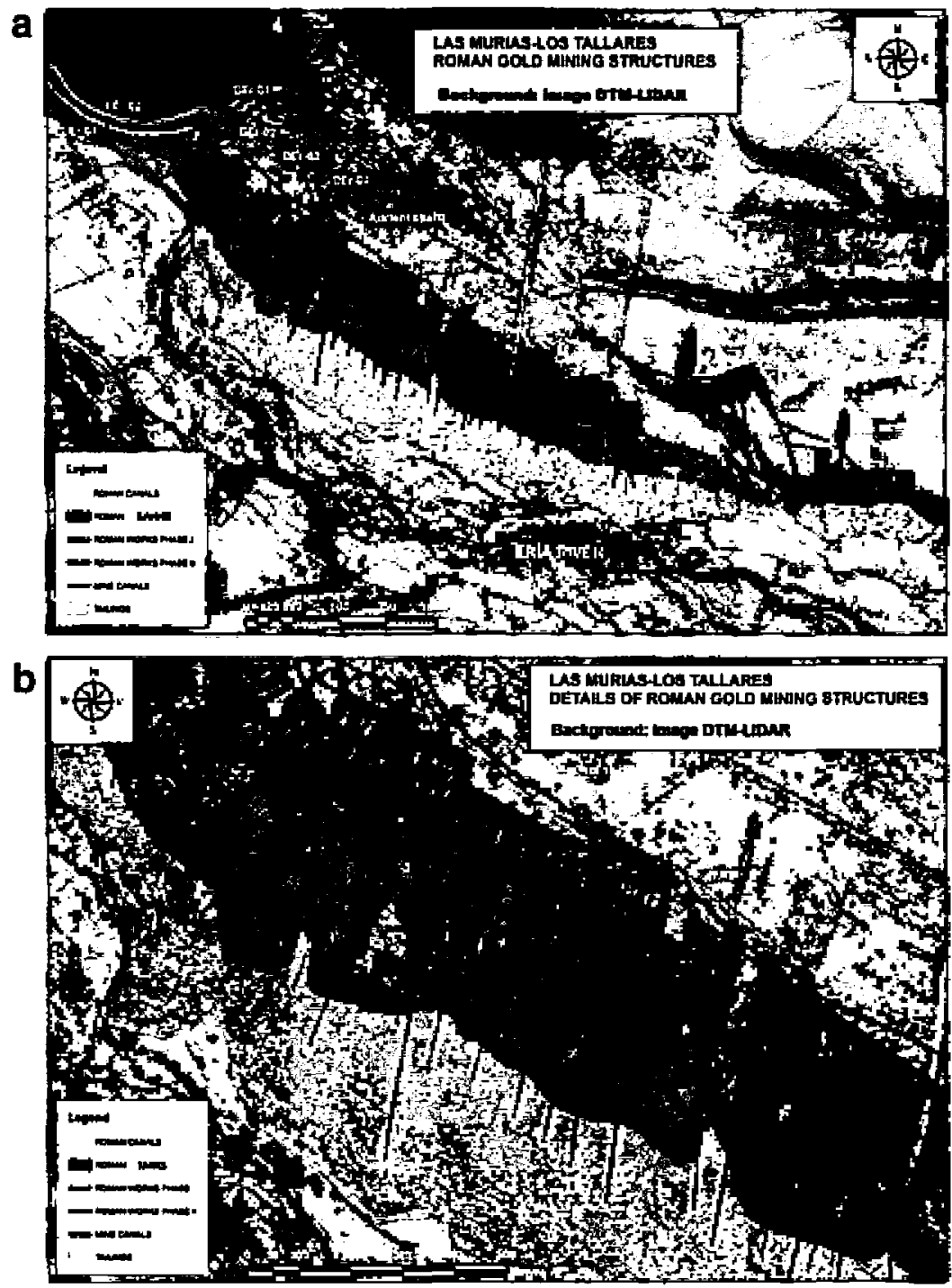

- Increased water gradient in the extraction areas by working with 8-10 m level changes which reduces its consumption as the effectiveness increases, also affecting the amount of necessary labor.

- Less loss of auriferous materials as the cleaning is always done in the same position.

- The possibility of extending the washing canals lengthwise as the plain is filled, thereby reducing possible losses of fine gold.

- Ease of tailing evacuation without interrupting the process.

Without any in-depth studies of the other major examples of Roman auriferous peines mining (Las Omañas and Las Moraceras), the possibility of using both procedures and even a combination of them must be accepted.

\section{Mining Phases}

It would be coherent to consider several work phases given the great longitudinal extension of the auriferous ore deposit. Pérez García (1977), pp. 186-187) already discussed three ascending mining phases completed by backwards on the terrace. In his exploration work, he located two already filled shafts on the upper plain which he attributes to Roman prospecting to establish the thickness and wealth of terrace T-2. Nonetheless, the singularity of these shafts which is not repeated in any other mining work for the area leads to the belief that they were completed in a more recent period related to the mining attempts in the 19th and 20th centuries (Fig. 15).

In the case of Las Murias-Los Tallares, the existence of two supply levels (CEr-01 and $\mathrm{CEr}-02$ ) does not correspond to two work phases given that both canals are above the maximum 
Fig. 10 a Accumulations of

tailing materials ("Murias")

within the areas of exploitation

(peines) after the fire of 2012, b

Accumulations of tailings in an

arca unaffected by the fire of 2012

a
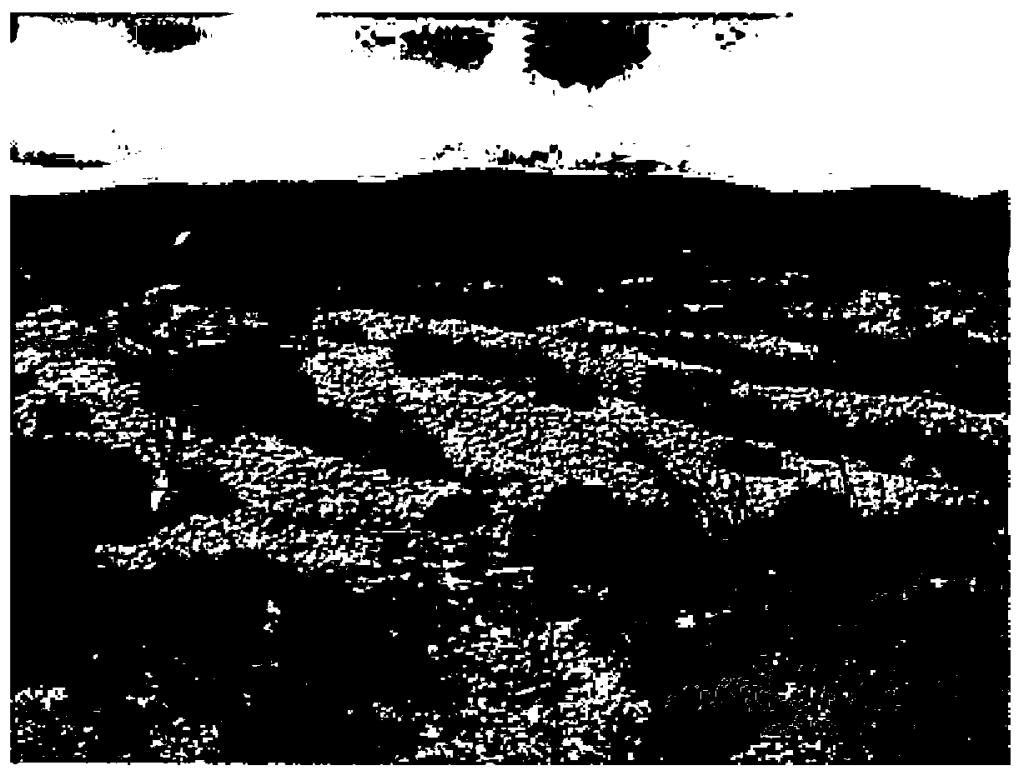

\section{b}

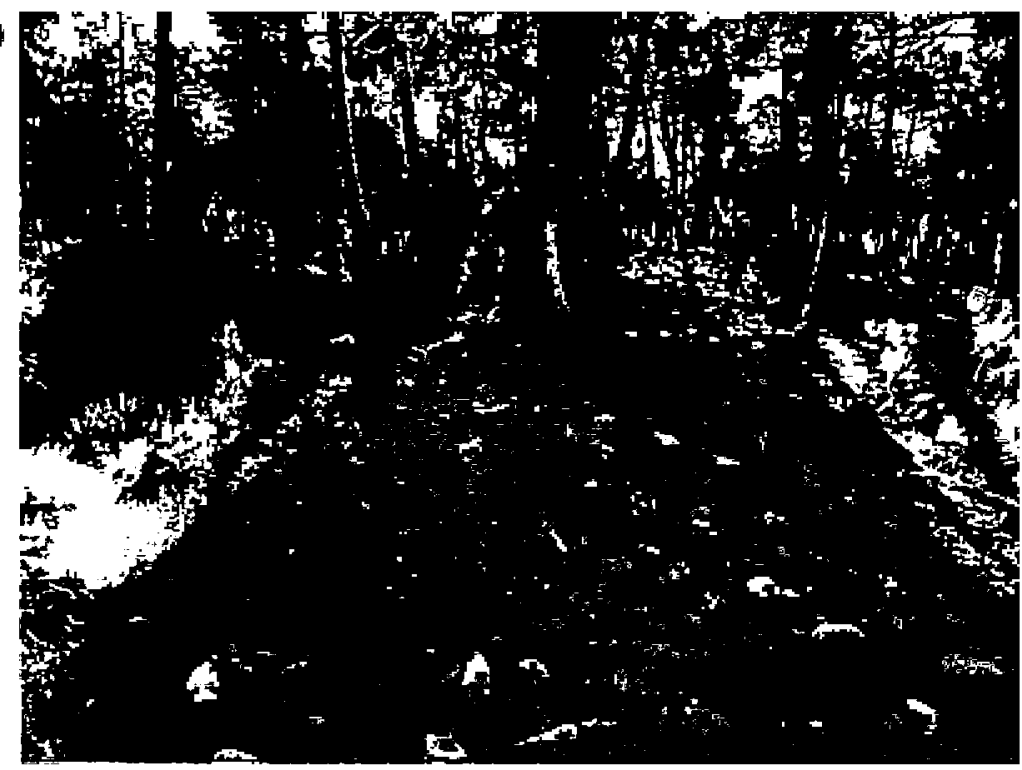

Io Pox $729309482,4675291.630$

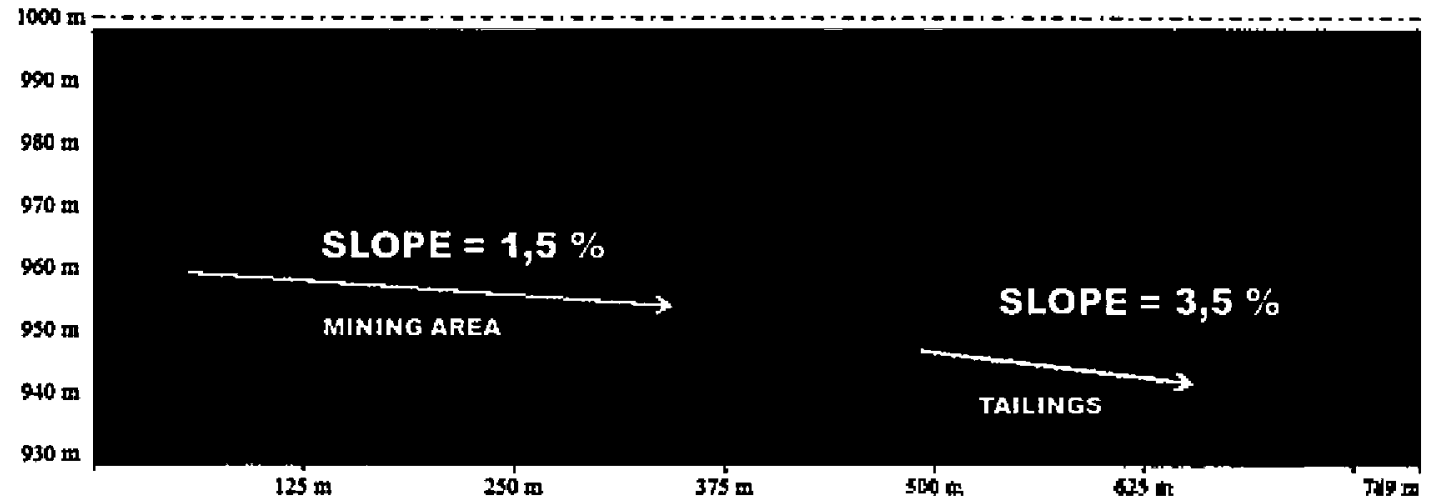

Fig. 11 Schematic profile of the muntng works showing the slopes 
Fig. 12 Miocene bedrock

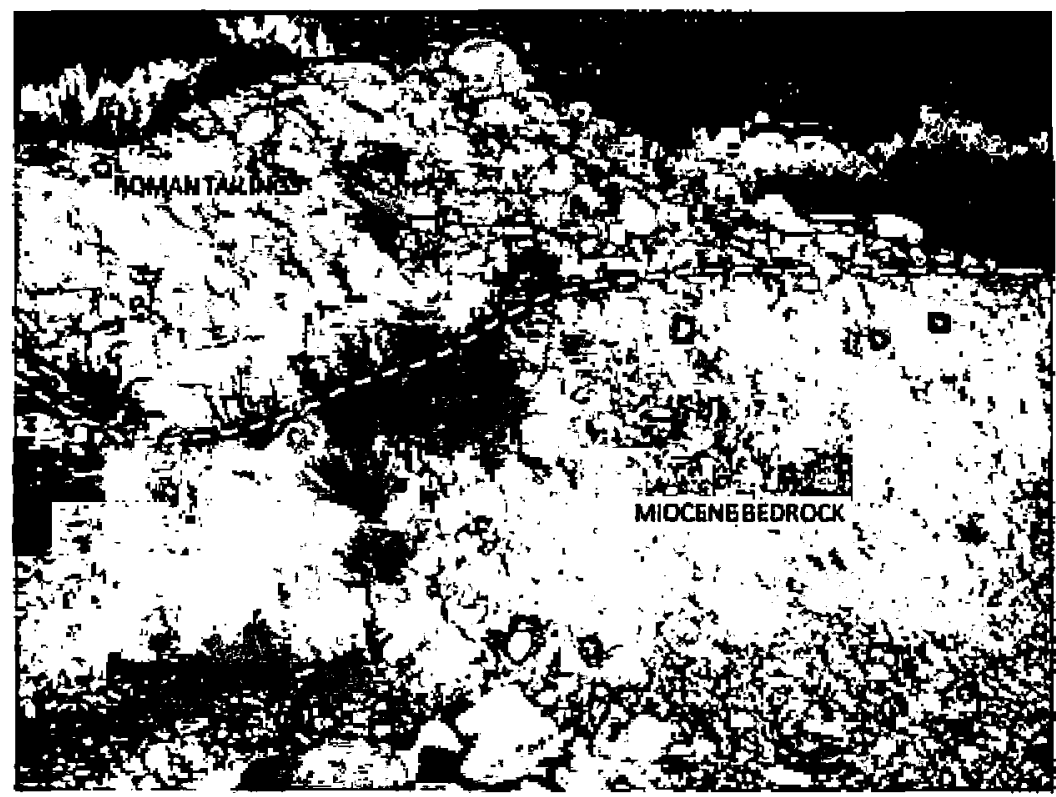

ore deposit elevation (Fig. Pa). Rather, it seems to be related to the need to simultaneously feed different sectors.

Nevertheless and after observing the structure and arrangement of the peines, the cxistence of at least two overlapping phases using different procedures can be easily observed. The first phase seems to have worked the first $120-150 \mathrm{~m}$ of the edge width of the T-2 terrace slope towards the plain while the second overlaps the first, reaching $450 \mathrm{~m}$. The presence of the first phase is detected almost all along the mine but it is particularly obvious on the eastem end.

The technology used in the two phases is the same, although greater regularity and surface area is noticeable in the peines in the second phase as well as a greater depth which sometimes distinguishes the two phases as part of the initial work was halted at a higher level than the final phase which hollows them out with the progression.

\section{Gold Recovery}

Simply remobilizing the auriferous alluvium with a cument of water and circulating it through a narrow canal causes the gold particles, which are 8.5 times heavier than the materials among which they are found, to quickly move to the bottom of the

Table 4 Roman auriferous mining. Peines system. Average slopes of the different elements

\begin{tabular}{llll}
\hline Mine & Extraction zone & Drainage canal & Evacuation canal \\
\hline Omañas & $3-4 \%$ & $3.5 * 5.75 \%$ & $6-6.5 \%$ \\
Moraceras & $2-3.8 \%$ & $3.80 \%$ & $3.37 .5 \%$ \\
Murias-Tallares & $1.2-1.7$ 定" & $2.3-4.3 \%$ & $2.9-4.2 \%$ \\
\hline
\end{tabular}

"The slops in the westem zone increises to 3.33 f. sludge where any natural or artificial obstacle easily retains them. This natural phenomenon is the basic principle behind ground sluicing, widely represented in The Agricola (1556, Book VIll), which demonstrates the conlinuity over time of this mining technique even though it did not receive any specific name until the nineteenth century. Nearly 2000 years before, Pliny described the gold recovery process in this way:

Plin.Nat.33.76: There is also yet another task to perform on the level ground. Trenches are excavated for the water to flow through-the Greek name for them means 'leads'; and these, which descend by steps, are floored with gorse-this is a plant resembling rosemary, which is rough and holds back the gold. The sides are closed in with planks, and the channels are carried on arches over steep pitches. Thus the earth carried along in the stream sticles down into the sed and the shattered mountain is washed away. (Translation by H. Rackham, W.H.S. Jones and D.E. Eichholz. Also Pérez and Matias 2001).

Based on Pliny's text. Domergue initially situates the washing canals in the evacuation canals, where was common to each mining unit with a great length due to the scarce slope (3.35\%). He bases this argument on the presence of large pebbles throughout the evacuation canal of the unit studied at Las Moraceras and the observations to this end from the existing bibliography on modern auriferous mining (Domergue [973; Domergue et al. 1988). Afterwards, the same author corrects the site of the washing canal, situating it towards the entrance to the evacuation canal (Domergue and Hérail 1978, p. 267).

As the size of the gold particles increase, the area the current must run for them to reach the bottom becomes less. This 
Fig. 13 Rest of expluitation canals that show the possibility of simultancous works on all the thickness of the gold layer (eastem sector). Orthoimane PNOA 2014-0.5 m

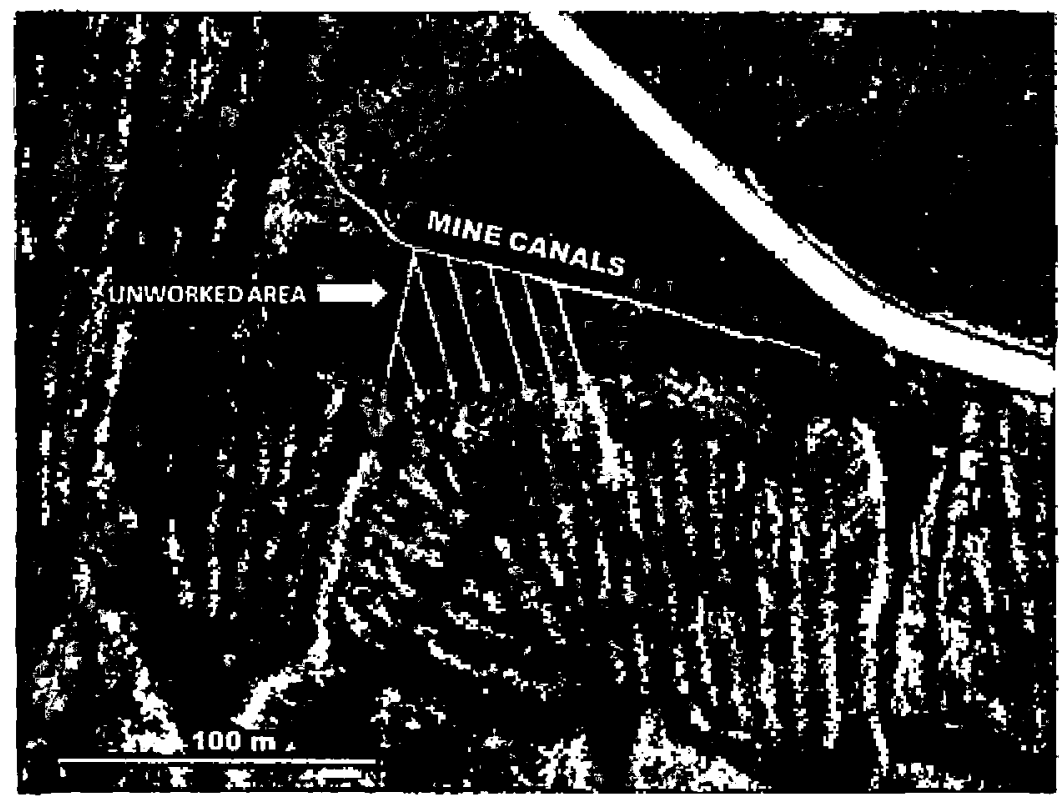

pp.195-196; Wilson 1912, p.43; Thome and Hooke 1929, pp. 51-56; Griffth 1960, pp. 120-121).

The position of the manual piles of pebbles does not seem to be sufficient criteria to establish the situation of the washing areas in the case at hand, as they are preferentially inside the peine area to the start faces. However, without any related archeological excavations that could determine the exact position of the washing canals, we would atso be inclined to believe that their position must have been in the evacuation canal which was the common point of passage for all extracted material. In fact, the very configuration of the ore deposit leads to the belief that if the washing canals had been in the same grooves, it would not have been necessary to use any common
Fig. 14 Rest of exploitation canals that show the possibility of simultaneous works on all the thickness of the gold tayer (westem sector). Pholograph of the USAF 1956-57 American Flight

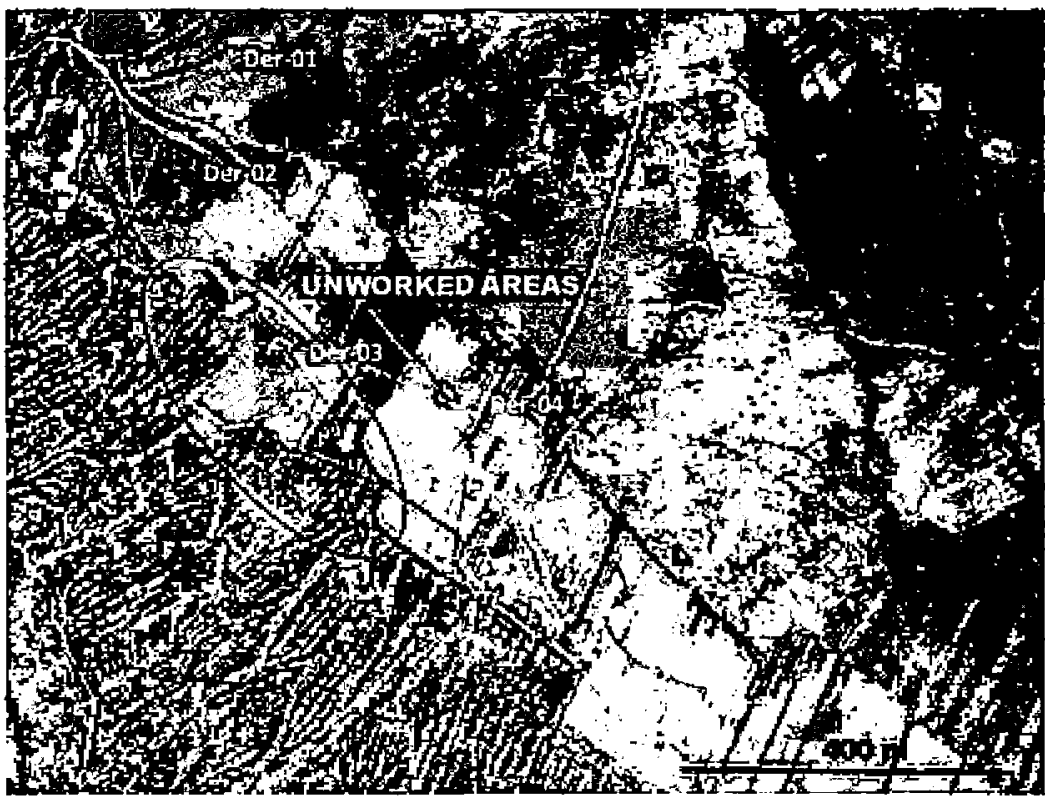




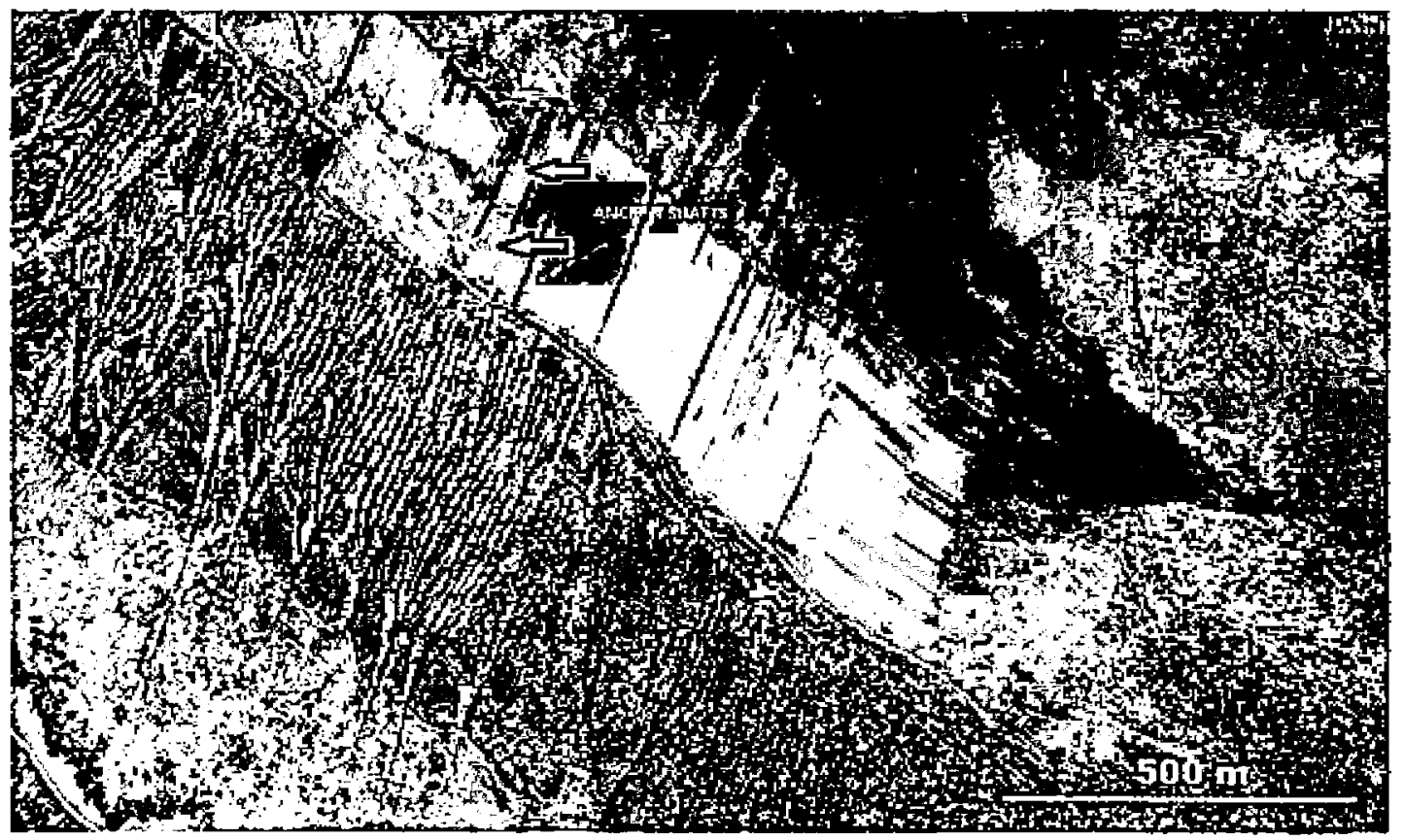

Fig. 15 Photograph of the USAF 1956--57 Amencan Flight of the central sector of the exploitation, where the exploration shafts are apprecialed

evacuation conduit and the tailings would have been directly dumped into the floodplain without leaving any residual rock.

The cubage of the tailings from the Las Murjas-Los Tallares Roman gold mine reflects a figure of nearly $6 \mathrm{Mm}^{3}$, for an extracted volume of materials of $11 \mathrm{Mm}^{3}$. LIDAR makes it spectacularly clear that the tailings were carried and deposited by the force of the water (Fig. 16).

\section{Discussion}

LIDAR data processing is now an essential tool for analyzing Roman hydraulic mining structures in NW I lispania, the limitations of which may be as follows:
- The quality and precision of the data collected in the LIDAR scanner

- The state of mine structure conservation

- The overlap of modem structures

- Working scale (general or detailed)

Although the posstbility of discovering new mining zones, most of which were already located in the 1970 s and 1980 s by means of extensive field explorations and meticulous photointerpretation work with stereoscopic images taken by archeologists Domergue ( 1987$)$ and Perea and SánchezPalencia (1995) is quite low, there is still a good outlook for this technology in areas covered with vegetation with the aforementioned limitations. However, LIDAR is not proving to be effective in locating small mines over outcroppings of
Fig. 16 DTM-LIDAR showing in detuil the accurnulation of tailings material on the current terrace of the Eria River

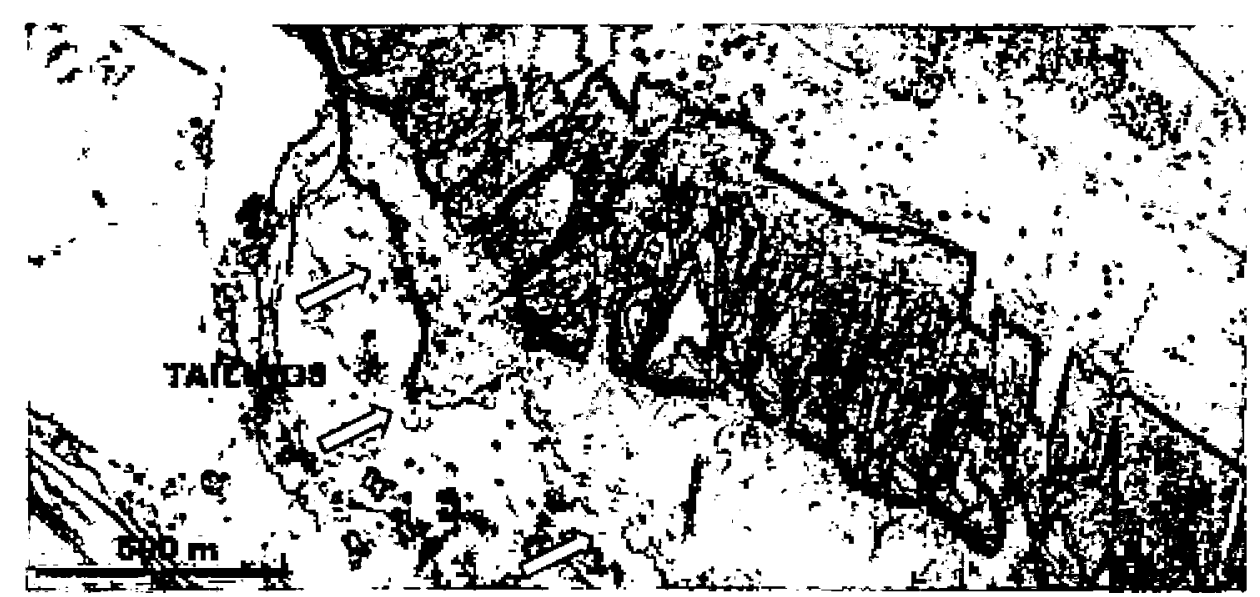


primary ore deposits, more than a dozen of which have already been documented in the area (Matias and GonzálezNistal 2014).

The use of LIDAR in the study area made it possible to locate and analyze hydraulic mining structures hidden by trees (tanks and extraction areas), which has greatly facilitated field explorations.

There is still much unknown information as to the work procedures due to the complex nature of the Las MuriasLos Tallares Roman gold mine meaning this analysis needs to be done on the other two major headframe Roman mines (Las Moraceras and Las Omañas) in order to compare the findings.

\section{Conclusions}

LIDAR technology was used to study the Las Murias-Los Tallares Roman gold mine (Castrocontrigo, León-Spain). This technique had to be combined with an analysis of historical photographs and orthoimages all while doing meticulous field work to collect in situ data as well as to verify the nature of some of the evidence observed in the DTM and aerial photographs. The combined use of these technologies helped understand the evolution of the mining works.

The analysis of the structure and arrangement of the peines show two main phases of ascending mine work. The total material dug up by the Romans is $11 \mathrm{Mm}^{3}$, which is $1 \mathrm{Mm}^{3}$ more than the figures offered by other authors.

The maximum mine depth level is limited by a practically sterile Miocene bedrock although there is not enough evidence to define the reasons limiting the extension of the Roman work towards the north although Rio Tinto Patiño, S.A. explorations show a very small gold content (average recoverable gold grade $58 \mathrm{mg} \mathrm{Au} \mathrm{m}^{3}$, with a maximum value of $81.5 \mathrm{mg} \mathrm{Auim} \mathrm{m}^{3}$ ). By applying a recovery rate of $80 \%$ of the dug up materials ( $11 \mathrm{Mm}^{3}$ ) to these dala, the Romans would have obtained $510.4 \mathrm{~kg}$ of gold. This figure should be considered with reservations as the Romans paralyzed mining efforts voluntarily at specific points, gradually moving all work to the west until the ore deposit was depleted which clearly indicates a possible decrease in grades towards the north, pursuant to the geological model of the ore deposit where the T-2 terrace reflects a gradual transition towards until the Miocene period.

The tailings were evacuated using the same water as was used for the extraction work, and they are accumulated in large artificial dejection cones in the Eria River floodplains. The cubage for these materials is $5.75 \mathrm{Mm}^{\mathrm{J}}$.

The moderate slopes of this ore deposit required the use of large volumes of water for mining, combined with plenty of labor to facilitate the water work on the alluviums.
Adknowledgements This work was done through collabordtion between the Regional Ministry of Culture and Tourism of Castilla y Lcon (Directorate General for Cultural Heritage) and the Gomez Pardo Foundation (Higher Technical Mining School of Madrid) in order to complete the projecl Actualización del Inventario de Mineria Aurifera Romana de Las Montes de León: Biera Oriental, Cabrera y Mamgateria (Fast (-2016).

\section{References}

Agricola G (1556) De Re Metallica. Traducción de Carmen Andreu Peon Unión Española de Explosivos, 2* ed. 1992, 601 pp

Bird DG (1972) The Roman gold mines of N.W. Of Spain. Bonner Jahrbüchen 172:36-64

Dieulafuit C, Dieulafait F, Domergue C, Fincker M y Picard V (2008) L'établirsementromain de Las Rubias, daus les mines d'or de la Sierra del Teleno (Corporales, province de León. Espuyne). En Actas del V Congreso Intemacional sobre Mincria y Metalurgia Antiguns en el Suroeste Europeo, León 2008, pp. 59-98. SEDPGYM, 2011

Domergue C (1973) La mise en valeur des gisements d'alluvions auriferes du nord-ouest de l'Espagne dans l'Antiquité' une technique d'exploitation romaine. Crónica del XII Congreso Arqueológico Nacional, Jaén 1971. Universidad de Zaragoza, pp 563-576

Domergue C (1987) Catalogue des mines et fonderies antiques de la Péninsule lbérique. Editorial de la Casa de Velázquez, Madrid. SérieArchéologie, 8, 2 Vol (Vol I, $244 \mathrm{p:} \mathrm{Vol} \mathrm{If} 117 \mathrm{p}$ )

Domengue C (1990) Les Mines de la Péninsule Ibèrique dans l'Antıquts' Romainc. École Francaise de Rome, Roma $625 \mathrm{p}$

Domergue C, Hérail G (1978) Mines d'or romaines d'Espagne: k district de la Valductra (province de león). Etude geomorphologique et arqueologique, CNRS, Toulouse $306 \mathrm{p}$. + planos

Domergue C, Fontan F \& Hérail G (1988) Quelques aspects de l'exploitation des giles aluviaux à l'époque romaine et de nos jours $113^{\circ}$ Congr, nat. Soc. savantes, Strasbourg 1988, Techniques minières. Comité des Travaux Historiques et Scientifiques, Paris 1992, pp L5-34

Fernández-Lozano J \& Gutićtrez Alonso G (2016) Improving archaeological prospection using localized UAVs assisted photogrammetry an example from the Roman Gold District of the Eria River Valley (NW Spain). J Archaeol Sci, https/ldoi.org/10.1016/j.jasrep.2016. 01.007

Fernandez-Lazano 1, Gutiérrez-Alonso G, Femandez-Morin M (2014) Using airorne LiDAR sensing technology and atrial onthoimages to unravel roman water sugply systems and gold works in NW Spain (Eria valley, Leon). J Archueol Sci 2014:356-373. hitps:!'doi.org' $10.1016 /$ j.jas.2014.11.003

Fonte J, Pires H, Gonçalves-Seco L، Matias R \& Lima A (2014) Archacological research of ancient mining landscapes in Galicia (Spain) using airbome laser scanning data. Puisagens mineitas antigas na Europa Ocidental, p 198. Boticas (Poruggal)

Gómez Femaindez F, Matias R, Mèndez AJ, Cifuentes J (2005) Estudio preliminar de las mineralizaciones de la mina de oro romana de Llamas de Cabrera (León. NO de España). Estud Geol 61:111-119

Gómez-Fernández F, Sänchez V. Vindel E, Martin-Crespo T, GonzilezClavijo E \& Matias $R$ (2010) Composición de las arsenopiritas $y$ evolución de los fluidos de los yacimictos primarios de oro de antiforme del Teleno (Leén). XXX Reunión de la Sociedad Fspañola de Mineralogia, 13-16 de Septiembre Madrid. Poster

Gómez-Femaindez F, Vindel E. Martin-Crespo T. Sínchez, V, GonzálezClavijo E, Matias R (2012) The llamas de Cabrera gold district, a new discovery on the Varisean basement of thorthwest Spain: a lluid inclusion an stable isotope study. Ore Geol Rev 46:68-82 
Griffith SV (1960) Alluvial prospecting and mining, 2nd edn. Pergamon Press, New York $246 \mathrm{pp}$

Férail G (1984) Géomophologie et gîtologie de l'or detritique. Pièmonts et bassins intramontagneux du nord-ouest de l'Espagne. CNRS. Paris $456 \mathrm{p}$

Jones RFJ. Bird DG (1972) Roman gold-mining in north-west Spain It: workings of the Rio Duema. J Romats Stud 62:59-74

Justel Cadiemo AM. Femández Lozano J, Femández Morin MA (2014) Ruta Romana del oro en la Valderia. Instituto Leones de Cultura. León

Levat D (1905) L'Industrie Aurifere. Dunod, ed, Paris, $898 \mathrm{pp}$

Lewis PR, Jones GDB (1970) Roman gold-mining in north-wist Spain. J Roman Stud 61:164-178

Longridge CC (1910) Hydraulic mining. The Mining Joumal, London, $352 \mathrm{pp}$

Matias $R$ (2005) La mineria autifera romana en la Sierra del Teleno (León-España): nuevos datos sobre su ingenieria y gestión. Actas del III Simposio sobre Mineria y Metalurgia Históticas en el Suroeste Europeo. Porto, 23-25 de Julio. Porto 2006, pp 211-229

Matias R (2006) La mineria aurifera romana del Noroesie de Hispania: Ingenicria Minera y Gestión de las explotaciones auriferas romanas en la Sierra del Teleno. En Nucvos Elementos de Ingenieria, Actas del ItI Congreso de las Obras Públicas Romanas (Astorga, 2006), pp 213-263

Matias R \& Gonzälez-Nistal S (2014) Delimitación de un nuevo y extenso yacimienı aurifero primario en la Sierta del Teleno (León-España) siguiendo las evidencias de mineria romana. Actas det XV Congreso Internacional sobre Patrimonio Geológico y Minero. XIX Sesión Cientifica de la SEDPGYM. Logrosín (Cáceres), 25-28 de steplitmbre del 2014

Matias R, Llamas B (2017) Use of LIDAR and photointerpretation to map the water supply at the Las Murias-Los Tallares Roman gold mine (Castrocontrigo, León-Spain). Archateological Prospection 2017. John Wiley \& Sons, Hoboken. pp I-1I

Perea A \& Sinchez-Palencin FJ (1995) Arqueologín del oro Astur: orfebreria y mineria. Caja Asturias, $116 \mathrm{p}$
Pírez Garcia LC (1977) Los sedimentos auriferos del No de la Cuenca del Duero (provincia de León-España) y su prospección. Tesis Doctoral. Inéduta. $450 \mathrm{p}$

Pírez M \& Matias R (2008) Plinio y la mineria aurffera romana: nueva tradueción e interpretación de Plin.Nat.33.66-78. Cuadernos de Filologín Clísica. Estudios Latinos 2008, 28, num. 1 43-58

Phillips JA (1867) The mining and metallurgy or gold and silver. E. and F.N. Spon, London, $532 \mathrm{pp}$

Ridley J (2013) Ore deposils geology. Cambridge University Press, Cambridge, $398 \mathrm{pp}$

Sáenz C, Vélez J (1974) Contribución al estudio de la mineria primitiva del oro en el Noroeste de España. Ediciones Atlas, Madrid $190 \mathrm{p}$

Sánchez-Palencia FJ (1977) La explotación aurifera prerromana y romana del noroeste de España. Memoria de Licenciatura. Universidad Complutense de Madrid. Facultad de Filosolia y Letras (Sección de Arte). Inédito, $206 \mathrm{pp}$

Sinchez-Palencia FJ (1980) Prospecciones en las explotaciones auriferas del N.O. de Espatan (Cuencas de los rios Eria y Cabrera y Sierra del Teleno). Noticiario Arqueológico Hispánico 8:214-289

Thome WE, Hooke AW (1929) Mining of alluvial deposits by dredging and hydraulicking. Mining Publications, London $172 \mathrm{pP}$

Tomos F (coord) (1992) Mapa Metalogenético de España. E 1:200.000. Hoja 18, Ponferrada. Instituto Tecsológico Geomintro de España. Madrid, 117 p. + plano

Tonos F, Ribera F (1993) Las mineralizaciones de oro en el sector meridional de la Zona Asturoccidental Lconesa: modelo melalogenético. ITGE. Ministerio de Industria y Energía, Madrid $78 \mathrm{p}$

Waldeyer C (1873) Hydraulic mining in Califomia. Statistics of Mines and Mining in the states and territoires west of the Rocky Mountains. Being the Fifth Annual Repon of Rossiter W. Raimon, 1873. Washington, pp 390-424

Wilson E (1912) Hydraulic and Placer Mining, 2nd edn. John Wilcy \& Sons, New York $356 \mathrm{pp}$ 